\title{
In vivo reflectance confocal microscopy for the diagnosis of scabies
}

\author{
Mihai Lupu, ${ }^{1,2}$ Vlad Mihai Voiculescu, ${ }^{1,3}$ Cristina Vajaitu, $^{3}$ Olguta Anca Orzan ${ }^{1,3}$
}

'Dermatology, Carol Davila University of Medicine and Pharmacy, Bucuresti, Romania ${ }^{2}$ Dermatology, Med-As Medical Center, Bucuresti, Romania ${ }^{3}$ Dermatology and Allergology, University Emergency Hospital Elias, Bucuresti, Romania

Correspondence to Dr Vlad Mihai Voiculescu; voiculescuvlad@yahoo.com

Accepted 16 December 2020

\section{DESCRIPTION}

Scabies is a common, contagious skin parasitosis typified by generalised pruritus and determined by Sarcoptes scabiei hominis. Standard diagnostic techniques for scabies consist of identification of the mite or its eggs by direct microscopic examination of skin scrapings and, in the past few years, of dermoscopy. ${ }^{1-3}$

In vivo reflectance confocal microscopy (RCM) is an emerging non-invasive imaging technique which produces horizontal greyscale images of the skin at various depths, allowing the visualisation of epidermis and superficial dermis at cellular resolution facilitating the diagnosis of several cutaneous disorders including skin cancers ${ }^{4-7}$ and
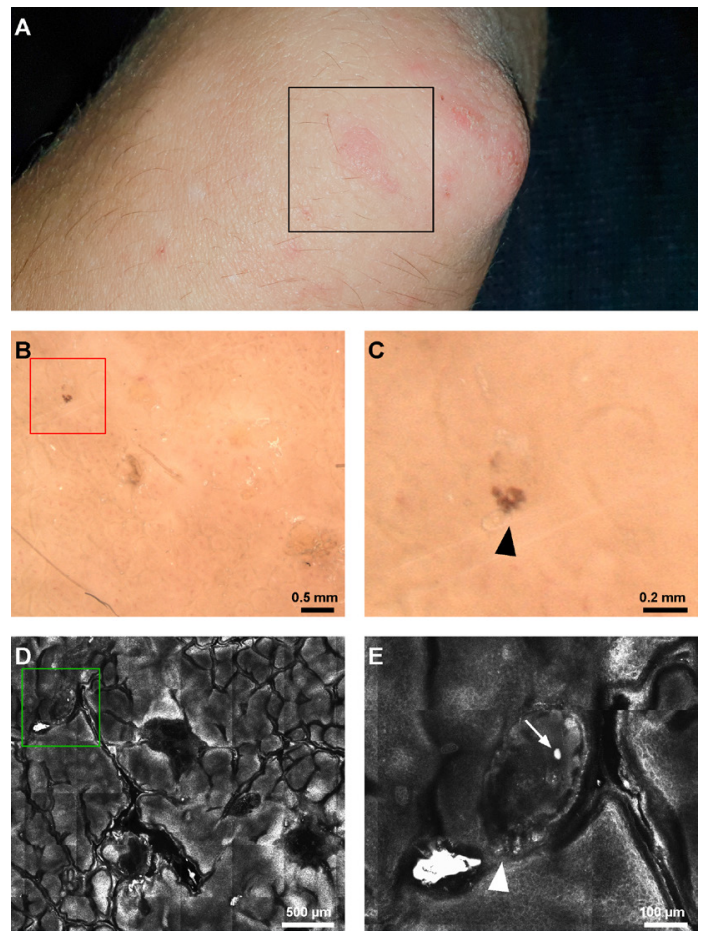

Figure 1 (A) Clinical photograph of the papules in the right elbow area. (B) Dermoscopy image of the lesion in the black square in $(A)$, revealing the mite (red square). (C) Dermoscopy image enlarged from (B), showing the 'delta-wing' sign (black arrowhead). (D) Reflectance confocal microscopy (RCM) mosaic $(3.2 \times 2.8 \mathrm{~mm})$ revealing parts of the burrow and the mite in the upper-left corner (green square). (E) RCM image $(780 \times 680 \mu \mathrm{m})$ showing the Sarcoptes scabiei mite with its inhomogeneously refractive ovoid body and its anterior pole with the rostrum (white arrowhead); highly refractive structure inside the mite, suggestive of faecal matter (white thin arrow). inflammatory skin diseases. ${ }^{8}$ RCM has previously been employed in the diagnosis of scabies, proving its ability to demonstrate the mite within the epidermis, where the adult women dig burrows and spawn. ${ }^{3-11}$

We report the case of a 36-year-old man with a 2-week history of diffuse, intense pruritus, and a generalised rash consisting of pink to red papules (figure 1A), in which skin scrapings performed by his primary care physician were negative. We performed dermoscopy and RCM of several lesions. Dermoscopy showed the classic 'deltawing' sign in a lesion located in the right elbow area (figure 1B,C). On confocal images, at a depth of $23 \mu \mathrm{m}$, the $S$. scabiei mite appeared as having an ovoid body (length $0.38 \mathrm{~mm}$; width $0.2 \mathrm{~mm}$ ) with an anterior pole presenting refractive structures corresponding to the two pairs of legs, a polygonal area, corresponding to the mite's head and a highly refractive ovoid structure $(23.8 \times 14.2 \mu \mathrm{m})$ inside the body contour, suggestive of faeces (figure 1D,E). The patient was started on topical treatment $(25 \%$ benzyl benzoate cream) and was doing well at 2 weeks' follow-up with full remission of the skin lesions and only slight, residual pruritus remaining.

The commercially available in vivo RCM VivaScope 1500 (Caliber I.D., New York, USA) was used for confocal imaging. The handheld version of this device (VivaScope 3000 Caliber I.D., New York, USA) has been shown to provide an even faster diagnosis, in similar cases. ${ }^{12}$

Although not indispensable, in our case RCM enabled the in vivo visualisation of the $S$. scabiei mite, thus enhancing the diagnosis. As already proposed by others, ${ }^{39}$ the combined examination by dermoscopy and RCM could represent an efficient and quick method to explore numerous lesions for

\section{Patient's perspective}

I came to the doctor's office seeking help for an itch that wouldn't go away. I was first seen by my primary care physician who, among other things, told me I might have scabies and ordered a test. The test came back negative and I was given some creams which I applied for about 2 weeks and the itch got better and then a lot worse. I couldn't sleep at night because I was scratching all the time, so I scheduled an appointment with a dermatologist, who, after a consult did a test, like an ultrasound and confirmed that I indeed have scabies. He started me on a treatment and in about a week I was already getting better. 


\section{Learning points}

A combined examination by dermoscopy and reflectance confocal microscopy could represent an efficient, quick and non-invasive method to explore numerous lesions for diagnostic confirmation of a clinically suspected scabies infestation.

- Reflectance confocal microscopy is currently available only in a limited number of centres, but may represent an alternative non-invasive tool for the diagnosis of scabies.

diagnostic confirmation of a clinically suspected scabies infestation. The identification of the parasite by RCM has been recently added among diagnostic criteria for scabies in the international guidelines. ${ }^{13}$

Contributors ML collected the clinical, dermoscopic and confocal images. VMV, $\mathrm{CV}$ and $\mathrm{OAO}$ contributed to literature research. ML, VMV, CV and OAO all critically reviewed the manuscript for intellectual content.

Funding The authors have not declared a specific grant for this research from any funding agency in the public, commercial or not-for-profit sectors.

Competing interests None declared.

Patient consent for publication Obtained.

Provenance and peer review Not commissioned; externally peer reviewed.

\section{REFERENCES}

1 Cinotti E, Perrot J-L, Labeille B, et al. [Diagnosis of scabies by high-magnification dermoscopy: the "delta-wing jet" appearance of Sarcoptes scabiei]. Ann Dermatol Venereol 2013;140:722-3.

2 Cinotti E, Labeille B, Cambazard F, et al. Videodermoscopy compared to reflectance confocal microscopy for the diagnosis of scabies. I Eur Acad Dermatol Venereol 2016;30:1573-7.

3 Micali G, Lacarrubba F, Verzì AE, et al. Scabies: advances in noninvasive diagnosis. PLoS Negl Trop Dis 2016;10:e0004691.

4 Lupu M, Caruntu A, Caruntu C, et al. Non-Invasive imaging of actinic cheilitis and squamous cell carcinoma of the lip. Mol Clin Oncol 2018;8:640-6.

5 Lupu M, Cãruntu C, Vâjâitu C. In vivo reflectance confocal microscopy of spokewheel structures in a pigmented basal cell carcinoma. Case report. DermatoVenerol 2019;64:11-16.

6 Lupu M, Popa IM, Voiculescu VM, et al. A retrospective study of the diagnostic accuracy of in vivo reflectance confocal microscopy for basal cell carcinoma diagnosis and subtyping. J Clin Med 2019;8:449.

7 llie MA, Caruntu C, Lupu M, et al. Current and future applications of confocal laser scanning microscopy imaging in skin oncology. Oncol Lett 2019;17:4102-11.

8 Ianoși SL, Forsea AM, Lupu M, et al. Role of modern imaging techniques for the in vivo diagnosis of lichen planus. Exp Ther Med 2019;17:1052-60.

9 Longo C, Bassoli S, Monari P, et al. Reflectance-mode confocal microscopy for the in vivo detection of Sarcoptes scabiei. Arch Dermatol 2005;141:1336-36.

10 Lacarrubba F, Verzi AE, Micali G. Detailed analysis of in vivo reflectance confocal microscopy for Sarcoptes scabiei hominis. Am J Med Sci 2015;350:414.

11 Cinotti E, Perrot JL, Labeille B, et al. Reflectance confocal microscopy for cutaneous infections and infestations. J Eur Acad Dermatol Venereol 2016;30:754-63.

12 Perrot J-L, Cinotti E, Labeille B, et al. [Rapid diagnosis of scabies by manual confocal reflectance microscopy]. Ann Dermatol Venereol 2012;139:502.

13 Engelman D, Yoshizumi J, Hay RJ, et al. The 2020 international alliance for the control of scabies consensus criteria for the diagnosis of scabies. Br J Dermatol 2020;183:808-20.

Copyright 2021 BMJ Publishing Group. All rights reserved. For permission to reuse any of this content visit

https://www.bmj.com/company/products-services/rights-and-licensing/permissions/

BMJ Case Report Fellows may re-use this article for personal use and teaching without any further permission.

Become a Fellow of BMJ Case Reports today and you can:

- Submit as many cases as you like

- Enjoy fast sympathetic peer review and rapid publication of accepted articles

- Access all the published articles

- Re-use any of the published material for personal use and teaching without further permission

Customer Service

If you have any further queries about your subscription, please contact our customer services team on +44 (0) 2071111105 or via email at support@bmj.com.

Visit casereports.bmj.com for more articles like this and to become a Fellow 